\title{
Coastal Agriculture and Its Challenges: A Case Study in Gosaba Island, Sundarban, India
}

Soumen Ghosh ${ }^{+*}$ and Dr Biswaranjan Mistri ${ }^{*}$

\section{Abstract}

Agriculture is the main economic activity in Sundarban to sustain the basic livelihood of rural people. In recent decades, the nature of agriculture mainly cropping pattern, crop productivity and agricultural land use is gradually changing because of various natural as well as anthropogenic factors. The frequent occurrence of climatic extremes over the Bay of Bengal has been directly or indirectly affected the agricultural system of the delta. In the wake of the 2009 cyclone Aila, the crop production in Gosaba rapidly declined due to high salinity and low pH in the soil. Most of the agricultural land remains a seasonal fallow due to the shortage of freshwater during the dry season. The direction of the surface slope has been altered by unsystematic construction of embankment and haphazard construction of closure in river channels. The saucer-shaped appearance of the island causes massive drainage congestion induced waterlogging problem in the agricultural field. Waterlogging causes crop damage and low productivity. Farmers continue to face substantial monetary loss and entrapping in poverty. To overcome these issues, climate-resilient cropping strategy, proper maintenance of the drainage system and adaptation of modern land reshaping techniques for diversified agriculture system are urgently needed for profound agro-based economic future of the delta.

Keywords: Agricultural Land Use; Cropping Pattern; Crop Productivity; Soil Characteristics; Waterlogging; Sundarban; India

\footnotetext{
${ }^{\dagger}$ Research Scholar, Department of Geography, The University of Burdwan, Bardhaman, West Bengal 713104, India.

${ }^{*}$ Corresponding Author, Email: ghoshsoumen864@gmail.com

${ }^{¥}$ Associate Professor, Department of Geography, The University of Burdwan, Bardhaman, West Bengal 713104, India, E-mail: brmistri@gmail.com

(C) 2020 Ghosh \& Mistri. This is an Open Access article distributed under the terms of the Creative Commons Attribution License (http://creativecommons.org/licenses/by/2.0), which permits unrestricted use, distribution, and reproduction in any medium, provided the original work is properly cited.
} 


\section{Introduction}

Sundarban is a low lying flat alluvial land dominated by monocropping. The history of agriculture in Sundarban dates back to the $16^{\text {th }}$ century. Rana Pratapaditya, one of the Bara Bhuiyans (local chief) and Khan Jahan next to him, tried to make the Sundarban as agricultural land or 'Abad'. The British rulers started the massive deforestation of mangrove forests during the 1870 s for land reclamation. They have constructed embankment to protect low lying coastal land from saline water intrusion and encouraged agricultural activities to ensure more revenue collection by the way of agricultural practices (O'Mally,1914). The average elevation of the Sundarban remains below the high tide line. Therefore, to prevent saline river water intrusion in the agricultural field is a significant challenge in the early $19^{\text {th }}$ century (Das et al., 2012). However, most recently, climate change has grown as another serious threat to coastal agricultures in Sundarban. The rapid sea-level rise, flood events and increasing frequency of cyclones have been changing the cropping pattern and production of crops in the tropical coastal region (Gupta and Sarkar, 2015). Farmers have practised rice-based farming system in low lying coastal land of Sundarban based on traditional methods (Bandyopadhyay et al., 2003). The mismanagement of drainage system still causes large scale water inundation during climatic extremes (Mistri, 2014, Ghosh and Mistri, 2020). As a result, farmers continue to face a massive loss in agricultural productivity due to high soil salinity (Debnath, 2013). Evidence suggests that the soil characteristics have changed after cyclone Aila in 2009 due to saline water ingression making the soil infertile (Halder and Debnath, 2014). Vegetable crops, especially production of red chilli, has rapidly declined (Samanta, 2018). Near about $44 \%$ of people are still living below the poverty line, and $87 \%$ of people suffer from food shortages in this Block (Halder and Debnath, 2014). Farmers are entrapped in the vicious cycle of poverty due to a lack of sustainable agricultural practices.
This study begins with a detailed review of existing literature followed by the geographical description of the study area and methodology of the research. As the study deals with the various issues and challenges of coastal agriculture, the next section highlights the pattern of agricultural land use in Gosaba Island. The research then turns on to discuss various types of cropping pattern with special reference to rice-based cropping system in this saline coastal zone. Thereafter, the trend of spatio-temporal change of paddy production has been shown from 2005 to 2019 with particular reference to the impact of the cyclone Aila in 2009. The next section elaborates about the significant challenges of coastal agriculture on this island. The study concludes with some fundamental suggestions to tackle these challenges for sustainable coastal agriculture and better livelihood of farmers.

\section{Review of Literature}

According to Indian Meteorological Department (IMD), Gosaba Island lies in High-Risk Zone in Climate Vulnerability Zonation Map of Indian Sundarban delta which is prepared based on climatic hazard and disaster study parameters such as frequency of cyclones, floods, breaching of embankment and storm surges (Halder and Debnath, 2014). The research studies conducted by Gupta and Sarkar (2015); Si (2016); Mahadevia and Vikas (2012) have shown the recent trend of climatic extremes and its impact on the agroclimatic condition of the island signaling that cyclone Aila adversely affected the cropping pattern and land-use system of the island (Debnath, 2013; Halder and Debnath, 2014; Samanta, 2018; Kar and Bandyopadhyay, 2015, Dhara and Paul, 2016). Indeed, the work of Si (2016) has shown the salinity concentration status in soil due to the effect of cyclone Aila and its negative impact on paddy production. Similarly, Wong et al. (2010); Shrivastava and Kumar (2015) and Manuel et al. (2017) discusses the effect of soil salinity on the growth of vegetable crops and suggests some management practices to reduce the level of soil and water salinity for sustainable agriculture. Mandal (2019), however, well describes various risks 
associated with coastal agriculture and profitability challenges caused by soil, water and climatic hazards. This study also emphasises on technological innovation and support in the policy framework for sustainable coastal agriculture. All these studies help understand various constraints of coastal agriculture, demonstrating the recent trend of crop production as well as cropping pattern on the island. The following section describes the study area.

\section{The Study Area}

The Sundarban delta is dissected by innumerable numbers of river channels (McSweeney, 2017). The delta formation took place in 125 million years ago (Halder and Debnath, 2014). According to Oldham (1893) the whole lower Bengal, including Sundarban is located between two major rivers Hugli in the west and Meghna (in Bangladesh) in the east. The Bengal delta was formed by the quaternary alluvium deposition carried down by the Ganga-Brahmaputra river system and its tributaries. It is also stated that the gradual submergence of the crust formed the delta due to excessive weight of quaternary alluvium deposition carried down by the rivers from the Himalaya (Bannerjee, 1998, Allison, 1998). The Gosaba block is a part of the largest estuarine ecosystem of Sundarban shared between India and Bangladesh. It lies within canning sub-division of South 24 Parganas district of West Bengal, India (Figure 1, Table 1). The areal extension of Gosaba is $21^{\circ} 54^{\prime} \mathrm{N}$ to $22^{\circ} 08^{\prime} \mathrm{N}$ and $88^{\circ} 29^{\prime} \mathrm{E}$ to $88^{\circ} 49^{\prime} \mathrm{E}$. River Bidya bounds the region in the west and rivers Gomar and Raimangal in the east. The Gosaba block consists of 14 Gram Panchayats (Amtali, Bali I and II, Bipradaspur, Chhota Mollakhali, Gosaba, Kachukhali, Kumirmari, Lahiripur, Pathankhali, Radhanagar-Taranagar, Rangabelia, Satjelia and Sambhunagar) and 50 inhabited villages (District Human Development Report, 2009). The total area of the study region is $296.43 \mathrm{sq} . \mathrm{Km}$ and the population density is 830 people/sq. Km (Census of India, 2011). The tropical monsoon climate dominates the region. The mean annual rainfall is $180-200 \mathrm{~cm}$, and $80 \%$ of the rainfall occurred during monsoon season (June to October). The annual temperature ranges between $21{ }^{\circ} \mathrm{C}-32^{\circ} \mathrm{C}$ and relative humidity varies from 70 to $80 \%$. The region is frequently affected by tropical cyclones due to the proximity of the Bay of Bengal (Rogers, 2014; Bandyopadhyay et al., 2003). Cyclones bring high tidal bore. The mean summer and winter temperature are about $29^{\circ} \mathrm{C}$ and $20^{\circ} \mathrm{C}$, respectively. The soil temperature is classified under the hyperthermic regime (Bandyopadhyay et al., 2003).

\section{Objectives of the Study}

The primary objectives of the study are as follows:

- To show the recent changes in the cropping pattern and agricultural land use pattern of the Gosaba island.

- To examine the changing trend of spatiotemporal variation of crop production with special reference to severe cyclone Aila, 2009.

- To identify the emerging challenges of coastal agriculture, act as a hindrance for farmers' sustainable livelihood.

\section{Methodology and Database}

To fulfil the objectives of the study, an intensive field survey was conducted to collect the information from farmers regarding cropping pattern, crop production, irrigation facilities and drainage system of the studied blocks. To aggregate primary data, a cross-sectional multilayered questionnaire was framed in the local language (Bengali) and surveyed accordingly with the help of a local guide. The questions were structured in both open and close-ended questions to give space of the respondents wherever possible. The questionnaire was surveyed from April 2017 to March 2019. Fifteen respondents (farmer belonging to the age cohort 35-60) were selected from each mouza using the random sampling method. To understand the soil characteristics, 30 soil samples $(0-20 \mathrm{~cm})$ were collected based on grid method from different agricultural fields of the entire block. These soil samples were tested using a soil testing kit to determine the Soil $\mathrm{pH}$ and Organic Carbon. Electrical Conductivity Meter (EC meter) was used to determine soil salinity. The obtained data was incorporated in the ArcGIS environment for 
spatial interpolation using Inverse Distance Land Records and Survey, Government of West Weighting (IDW) method. Climate-related data Bengal. Different types of relevant secondary were collected from the Indian Meteorological data were also gathered from various books and Department (IMD). Agricultural land use map of journals to make this study empirical. the Gosaba block was prepared by Directorate of

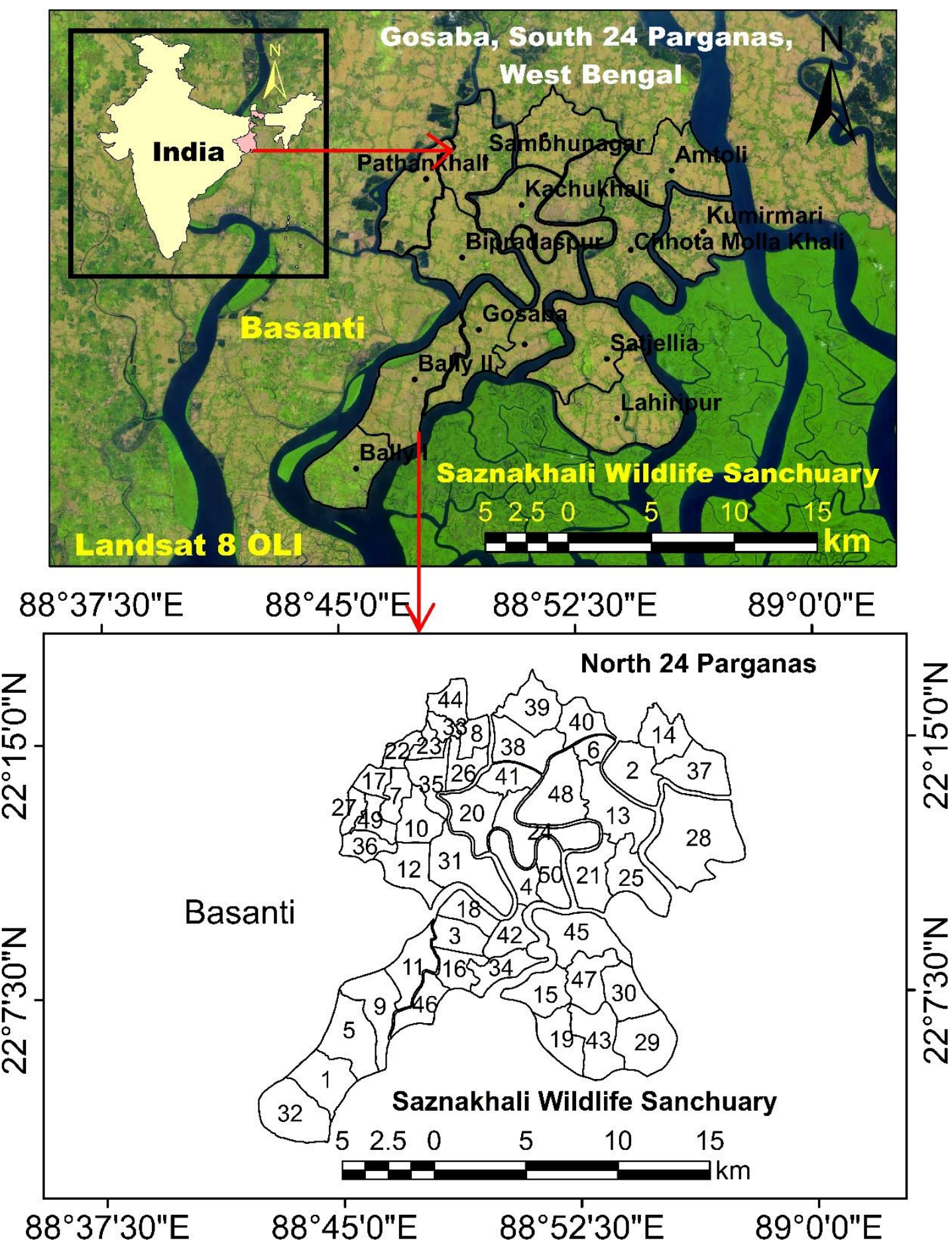

Figure 1: Location of the Study Area Source: Authors 
Table 1: Details of Mouza and Respective Gram Panchayat

Gosaba C.D. Block, South 24 Parganas, West Bengal

\begin{tabular}{|c|c|c|c|}
\hline Mouza Id & Mouza Name & GP Name & Area* (In hector) \\
\hline 1 & Amlamethi & Bally I & 1039.45 \\
\hline 2 & Amtali & Amtali & 711.08 \\
\hline 3 & Arampur & Gosaba & 446.43 \\
\hline 4 & Bagbagan & Rangabelia & 460.85 \\
\hline 5 & Bally & Bally II & 944.49 \\
\hline 6 & Baramollakhali & Radhanagar Taranagar & 433.60 \\
\hline 7 & Battali & Pathankhali & 320.6 \\
\hline 8 & Bhupendrapur & Sambhunagar & 298.72 \\
\hline 9 & Bijoynagar & Bally II & 652.85 \\
\hline 10 & Biprodaspur & Biprodaspur & 503.79 \\
\hline 11 & Birajnagar & Bally II & 615.33 \\
\hline 12 & Chandipur & Biprodaspur & 716.2 \\
\hline 13 & Choto Molla Khali & Choto Molla Khali & 1063.63 \\
\hline 14 & Chimta & Amtali & 656.18 \\
\hline 15 & Dayapur & Satjelia & 633.4 \\
\hline 16 & Dulki & Gosaba & 419.39 \\
\hline 17 & Gopalkata & Pathankhali & 249.3 \\
\hline 18 & Gosaba & Gosaba & 318.94 \\
\hline 19 & Hamilton Abad & Lahiripur & 602.98 \\
\hline 20 & Harishpur & Kachukhali & 679.8 \\
\hline 21 & Hetalbari & Choto Molla Khali & 512.79 \\
\hline 22 & Jelepara & Pathankhali & 236.8 \\
\hline 23 & Jhaukhali & Sambhunagar & 223.33 \\
\hline 24 & Kachu Khali & Kachu Khali & 716.31 \\
\hline 25 & Kalidaspur & Choto Molla Khali & 678.94 \\
\hline 26 & Kamakhyapur & Sambhunagar & 404.61 \\
\hline 27 & Kamarpara & Pathankhali & 215.2 \\
\hline 28 & Kumirmari & Kumirmari & 2020.8 \\
\hline 29 & Lahiripur & Lahiripur & 851.05 \\
\hline 30 & Luxbagan & Lahiripur & 609.46 \\
\hline 31 & Manmathanagar & Bipradaspur & 998.63 \\
\hline 32 & Mathurakhanda & Bally I & 785.6 \\
\hline 33 & Mitrapur & Sambhunagar & 154.27 \\
\hline 34 & Pakhiralay & Rangabelia & 479.49 \\
\hline 35 & Palpur & Sambhunagar & 488.84 \\
\hline 36 & Pathankhali & Pathankhali & 344.77 \\
\hline 37 & Puinjali & Amtali & 673.51 \\
\hline 38 & Radhanagar Dakshin & Radhanagar Taranagar & 738.15 \\
\hline 39 & Radhanagar Paschim & Radhanagar Taranagar & 693.38 \\
\hline 40 & Radhanagar Purba & Radhanagar Taranagar & 439.1 \\
\hline 41 & Ramnagar & Kachukhali & 407.48 \\
\hline 42 & Rangabalia & Rangabelia & 464.43 \\
\hline 43 & Sadhupur & Lahiripur & 818.28 \\
\hline 44 & Sambhunagar & Sambhunagar & 381.45 \\
\hline 45 & Satjelia & Satjelia & 965.9 \\
\hline 46 & Sonagar & Gosaba & 476.47 \\
\hline 47 & Sudhansupur & Satjelia & 579.92 \\
\hline 48 & Taranagar & Radhanagar Taranagar & 808.3 \\
\hline 49 & Tentulia & Pathankhali & 300.9 \\
\hline 50 & Uttar Danga & Rangabelia & 437.18 \\
\hline
\end{tabular}




\section{Results and Discussion}

\section{The Pattern of Agricultural Land Use in Gosaba} Island

The agricultural land use pattern of Gosaba Island is primarily monocropping (Figure- 2). The land use map shows that $80 \%$ of the total agricultural land is under paddy cultivation. Paddy is grown as a Kharif Crop, which depends on the availability of rainfall in the monsoon season (Halder and Debnath, 2014). The Aman paddy is cultivated in the month of May-June. The low lying flat alluvial plain is ideal for paddy cultivation as it is a highly water-consuming crop (Mistri, 2014). The rest $20 \%$ area of agricultural land is used for crop rotation with some vegetables depending on the availability of irrigation water (Halder and Debnath, 2014). As stated earlier, the cropping pattern in Sundarban has changed after cyclone Aila in 2009 due to high salinity concentration in surface soil. The production of different types of vegetables like chilli, sugarcane and pulses has declined (Debnath, 2013; Samanta, 2018). Most of the agricultural land remains as temporal fallow in rabi season due to lack of irrigation facilities. However, a few farmers can practice Boro paddy cultivation depending on the availability of water from the irrigation pond. The sowing time of paddy during Rabi season is November to February and harvesting time is March to June. The low lying agricultural land is used for ricefish farming where the field has sufficient water retaining capacity for a long time and free from massive flooding due to embankment breaching. The practice of rice-fish farming is quite profitable in the coastal zone of Sundarban (Roy et al., 2004). Recently, Rice-Boro-Rice and RiceAquaculture are the two most crucial farming systems, commonly practised in Gosaba Island.

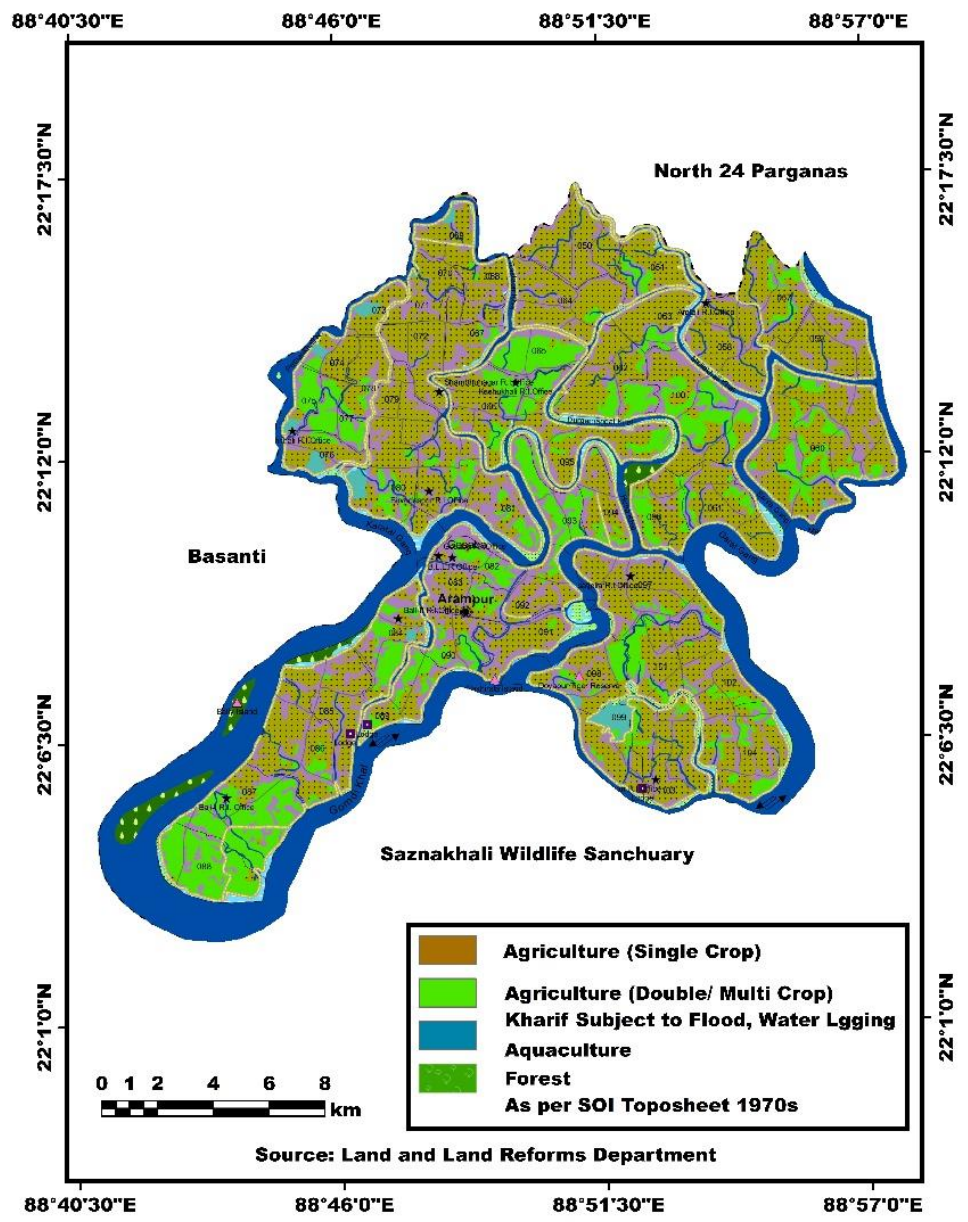

Figure 2: Pattern of Agricultural Land Use in Gosaba Island Source: Directorate of Land Records and Survey, Government of West Bengal 


\section{Types of Land Use and Cropping Pattern}

The morphological appearance of the delta is saucer-shaped, where the central part of the island is comparatively lower than its peripheral zone (Mistri, 2014). The appearance of saucershaped land is the result of unsystematic construction of embankment during the period of British colonial legacy. The intensive siltation within river channels and surrounding land gradually increase the elevation of the adjacent land of river channels as compared to the inland areas. The uneven distribution of sediment has been changed the direction of the surface slope (Ghosh and Mistri, 2014). The agricultural land faces huge waterlogging due to flawed drainage system and becomes unsuitable for cultivation of vegetable crops, especially in the Kharif season. The entire delta is classified into three zones based on the nature of the land and cropping pattern (Tables 2 and 3 ).

Table 2: Types of Land Use and Cropping System
\begin{tabular}{c|l} 
Type of land & Major Crops \\
\hline Upland & Aman-Boro Paddy, Vegetables, Potato, Pulses \\
\hline Medium land & $\begin{array}{l}\text { Aman Paddy, Fallow-Boro Paddy, Pulses, Summer Vegetables, } \\
\text { Commercial Crop (Sugarcane, Sugar, Jute and Green Manure Crops) }\end{array}$ \\
\hline Low land & Aman Paddy, Seasonal Fallow-Boro Paddy, Fiber Crops \\
\hline
\end{tabular} Source: Agriculture and Development Office, Gosaba, 2019

Table 3: Rice Base Cropping Pattern of Saline Coastal Zone

\begin{tabular}{|c|l|l|l|}
\hline 1 & Fallow-Rice-Pulse & $\mathbf{5}$ & Fallow-Rice-Cucumber \\
\hline $\mathbf{2}$ & Fallow-Rice-Sunflower & $\mathbf{6}$ & Fallow-Rice-Watermelon \\
\hline 3 & Fallow-Rise-Chilli & 7 & Fallow-Rice-Cotton \\
\hline 4 & Rice-Rice-Mung & $\mathbf{8}$ & Dhanicha-Rice-Rice \\
\hline \multicolumn{2}{|l|}{ Source: Rice Knowledge Management Portal, http://www.rkmp.co.in 18 February 2019} \\
\cline { 2 - 4 }
\end{tabular}

\section{Changing Trend of Crop Production}

The production trend of paddy has been studied for the last 15 years (2005-2019) to understand the changing trend of crop production. The data have been collected directly from farmers based on their perception. The study reveals that the trends of production of Aman and Boro paddy have remarkably changed post-cyclone Aila in 2009. The average production of Aman and Boro paddy at mouza level before Aila (2005-2008) were 1.44 tons/acres and 2.86 tons/acres, respectively (Figures $3 a \& 3 b$ ). Indeed, the production has reduced notably the cyclone Aila. The average productions from 2009 to 2013 were 0.74 tons/acres and 1.21 tons/acres for Aman and Boro paddy, respectively (Figures $3 c$ \& $3 d)$. The average salinity of soil during the winter season was $1.4-1.6 \%$ o before Aila, which was increased to $2-2.6 \%$ in post-Aila. This observation validates the study by Debnath and Halder in 2014. The average soil salinity is slightly decreasing in recent years as recorded by
Tagore Society for Rural Development (TSRD), situated at Rangabellia in Gosaba block. This institution collects soil samples from different agricultural fields and tests in their laboratory to help farmers for agricultural issues. According to their record, the soil salinity (during survey period 2018-2019) varies between 1.8 to $2.0 \%$. The decreasing trend of soil salinity almost ten years after cyclonic effect of Aila is quite favourable for crop production especially Aman and Boro paddy that shows 1.32 tons/acres and 2.72 tons/acres respectively (Figures- $3 e$ \& $3 f$ ). There are different types of salt-tolerant rice varieties like Nonabokra, Matla, Hamilton, Ghetu, Patnai 23, Lunishree is used in high salinity affected areas in this block. The average production potential of these types of rice varieties is recorded 2.0-2.5 tons/hectare. However, the production status of salt-tolerant rice varieties in Gosaba is comparatively lower than its actual potential due to the hostile environment of the island. 

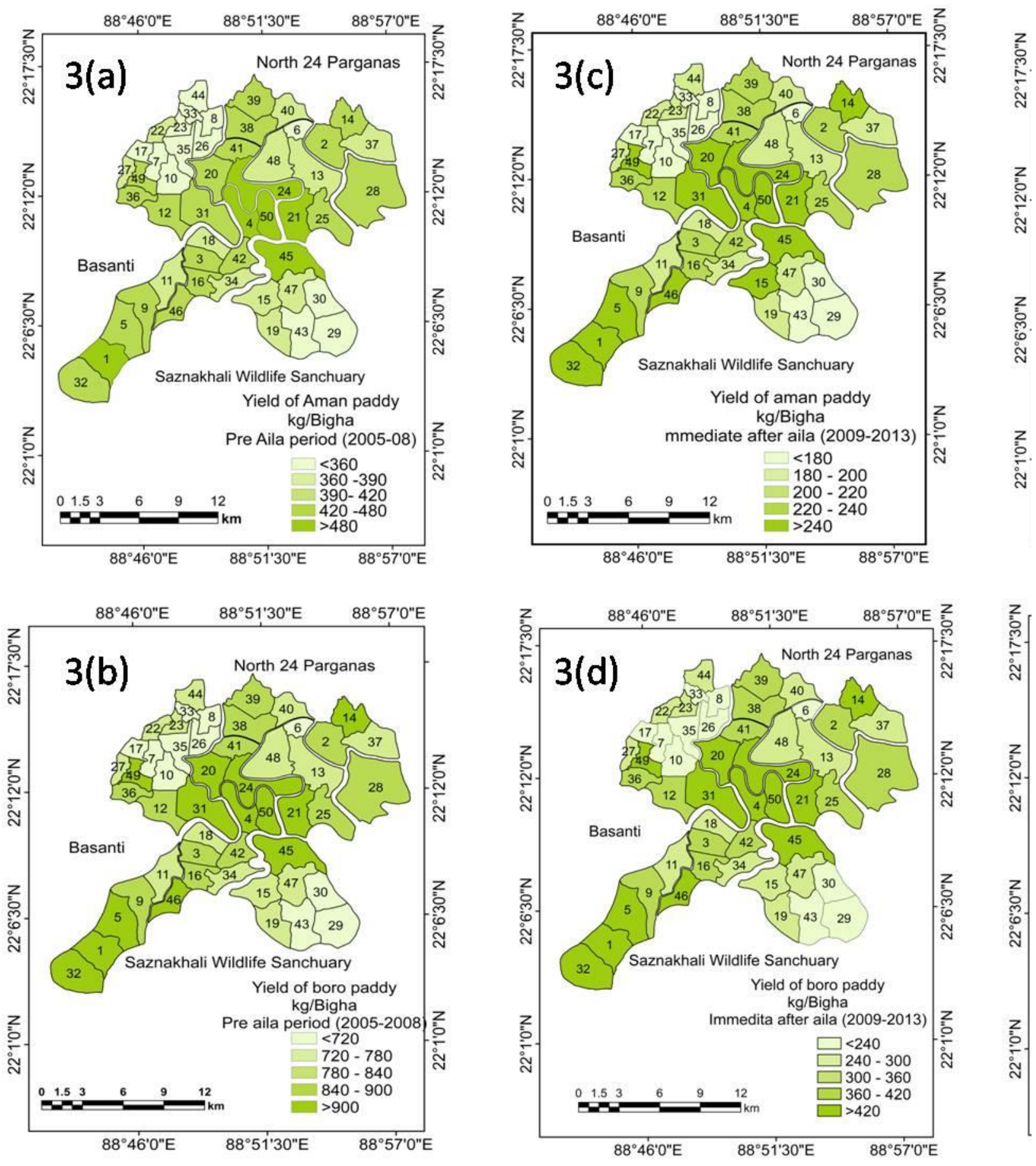

Figure 3: Production of Aman and Boro Paddy Source: Field Survey 2018-2019

\section{Major Challenges of Agriculture in Gosaba Island}

\section{Soil Characteristics}

Crop productivity depends on the characteristics of the soil. The actual potentiality of crop production is decreasing in Gosaba due to high salinity, acidic nature of the soil and low organic carbon concentration. The desirable $\mathrm{pH}$ range for optimum production of crop varies according to crop varieties. There are some High Yielding Varieties (HYV) of rice which are well suited between $\mathrm{pH}$ range 6.0 to 7.0 like Govindobhog, Satabdi and Pratikha and some other varieties of 
rice like Lunishree, Nonaboikhra and Matla are well grown in slightly acidic soil (Bandopyadhyay et al., 2003). The most favourable Soil $\mathrm{pH}$ range for ideal plant growth is 5.5-6.5, but the acidic nature of sub-surface soil creates hindrances for root access of water and nutrients for crop growth. The most critical nutrients for plant growth (NPK) are not available in strongly acidic soil, and it decreases crop production despite the adequate application of fertilizers in cultivable land (Chakraborty and Mistri, 2018). The total geographical area of strongly acidic soil is $239.68 \mathrm{sq}$. $\mathrm{Km}$ ( $79 \%$ of total geographical area) where $\mathrm{pH}$ is $<5$ and the total geographical area of slightly acidic soil is $61.42 \mathrm{sq}$. $\mathrm{Km} \mathrm{(21 \%} \mathrm{of} \mathrm{the}$ total geographical area) where $\mathrm{pH}$ value is $>5$ (Figure 4a). Therefore, strongly acidic nature of the soil in the Gosaba block is one of the significant hindrances for crop production. Another major challenge of coastal soil is salinity. The soil salinity is a result of the capillary movement of water from the groundwater table and accumulation of salt over surface soil through evaporation of water (Bandopyadhyay et al., 2003). The increasing salinity in soil has not only been declined the production of crops but also affected physiochemical properties of soil (Hu and Schmidhalter, 2002; Shrivastava and Kumar, 2015). Ingression of saline water during high tide and climatic extremes have been increasing the rate of salinization. The soil salinity varies depending on relative position of land and water (river and seawater) interface, the nature of soil capillaries and salinity level in groundwater (Bandopyadhyay et al., 2003; Si, 2016). The salinity increases in the dry season due to high rate of evaporation and upward capillary movement of saline groundwater, but salinity reduces in the rainy season because of leaching and washing of salts through rainwater (Bandopyadhyay et al., 2003; Halder and Debnath, 2014). The study block is highly sensitive to salinity. The entire block has been classified into four salinity groups such as very low salinity $(<0.39 \mathrm{ds} / \mathrm{m})$, low salinity $(0.39-0.66$ $\mathrm{ds} / \mathrm{m})$, moderate salinity $(0.66-0.93 \mathrm{ds} / \mathrm{m})$ and high salinity $(>0.93 \mathrm{ds} / \mathrm{m})$. The total geographical area of high salinity $(>0.6 \mathrm{ds} / \mathrm{m})$ is $162.45 \mathrm{sq} . \mathrm{Km}$ which constitutes $54 \%$ of the total geographical area of the block and the remaining $46 \%$ (138.65 sq. $\mathrm{Km}$ ) area where salinity remains below 6 $\mathrm{ds} / \mathrm{m}$ (Figures $4 \mathrm{~b}$ ). Soil organic carbon is another essential factor to maintain soil fertility. It supplies various nutrients for plant growth and enhances the biological and physical health of the soil. However, extreme salinization and poor growth of plants reduce the concentration of organic carbon in soil (Wong, 2010). The organic carbon concentration in soil is less than $5.5 \%$ over 224 sq. $\mathrm{Km}$ area which accounts for $74 \%$ of the total geographical area of Gosaba (Figure 4c). The restoration of soil health essentially needs to improve the agricultural production of the study area.
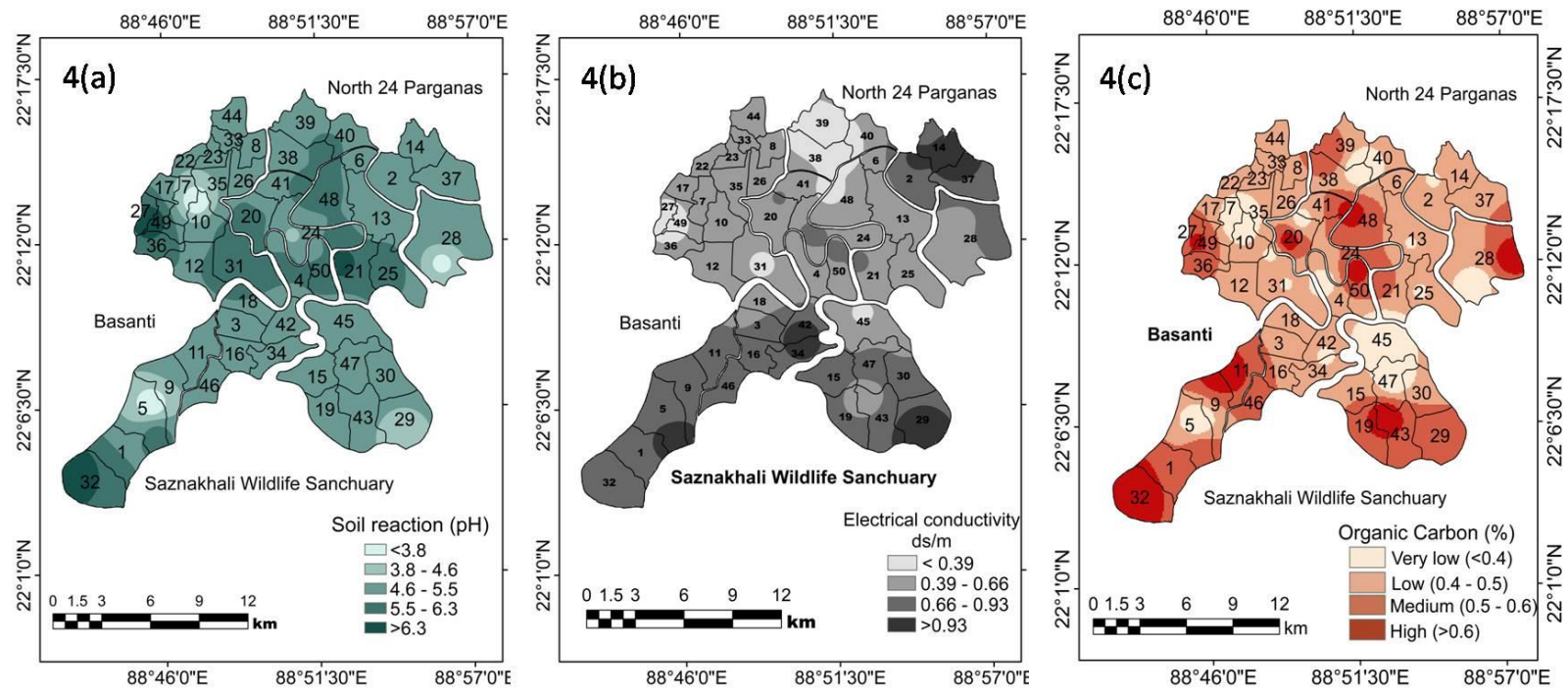

Figure 4: Soil Characteristics of Gosaba C.D. Block Source: Field Survey 2018-2019 


\section{Lack of Fresh Water for Irrigation}

The lack of a sufficient supply of freshwater is a significant problem for irrigation. The framers depend on monsoon for irrigation. An intrinsic network of river channels crisscrosses Gosaba. The rivers are mostly tidal. The farmers do not use water of tidally active channel due to high salinity. Only canals (khals) which are not connected with its parent rivers are used for storage of rainwater. During the field survey, it was observed that only $14.65 \%$ of farmers depend on such canals (khals) for irrigation (Figure 5a). The farmers are allowed to take the lease of the canal for a certain period from local village panchayat. The farmers who have extensive size land holdings and economically stable can afford lease facility. Canal water helps farmers during Rabi season, but $28 \%$ of the farmers irrespective of the size of landholding depend on rainwater for irrigation during Kharif season. Farmers store rainwater in their respective farming ponds because of the uncertainty of the rainfall in monsoon (Figures $5 b$ and 5c). The study shows that $49.23 \%$ respondent depends on farm ponds for irrigation. In Gosaba, Arampur, Dulki, Pakhiralay and Rangabellia mouza people cannot access groundwater for irrigation even there is no tube well for safe drinking water as the groundwater table remains below 500-1400 feet from the surface (Danda et al., 2011). Only $8.54 \%$ of people of this block can access a very little amount of ground-water through tube well to sustain the daily livelihood. Due to lack of irrigation facilities, most of the agricultural fields remain as a seasonal fallow during Rabi season.

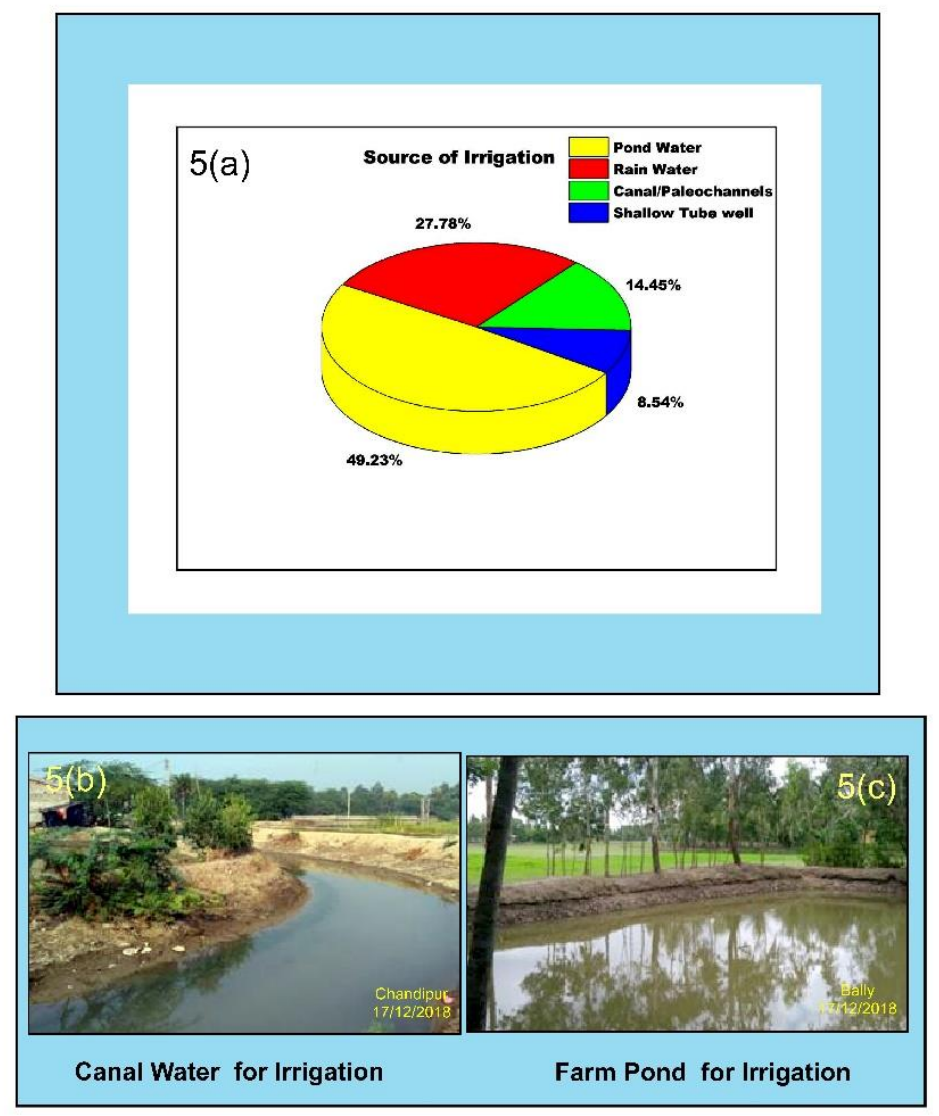

Figure 5 -Sources of Irrigation (Figures $5 a, 5 b$ and $5 c$ ) Source: Field Survey 2018-2019 


\section{Drainage Congestion and Waterlogging Problem}

The saucer-shaped landscape, flat topography, the seasonal occurrence of rainfall, low hydraulic conductivity of soil and mismanagement of drainage system are the major reasons of prolonged waterlogging in the agricultural field especially during monsoon season (Bandyopadhyay et al., 2003). The rapid human encroachment on drainage creates drainage congestion induced waterlogging problem (Figure 6a). River channels have been disconnected from their parent source. The construction of embankment in early 19th Century to prevent saltwater intrusion in agricultural soil has been raising siltation within channels and slowly increasing the elevation of the adjacent channel area than the inland areas (Bannerjee, 1998; Ghosh and Mistri, 2020). As a result, the saucer-shaped appearance of agricultural land is prone to waterlogging and decreases agricultural production (Mistri, 2012). The mismanagement of internal drainage system due to various human activities has aggravated the problem of waterlogging. The sluice gates are (discharge of countryside water into the river) not adequately maintained for smooth circulation of water. It creates a devastating impact on crop production during extreme climatic events (Figure $6 \mathrm{~b}$ ). In the rainy season, the water table remains close to the surface therefore internal percolation of water is almost negligible. The soil salinity increases in the postmonsoon period due to excessive evaporation of moisture and accumulation of salts at the root zone of soil (Bandyopadhyay et al., 2003). The farmers who are unable to cultivate their land due to excessive salinity, sometimes practice paddy-fish farming in their low lying waterlogged agricultural land, commonly found in Bally I, Bally II, Birajnagar, Satjelia and Kumirmari Gram Panchayat (Figure 6c).

\section{Lack of Scientific Knowledge of Agriculture}

Climate change is a global phenomenon. Climate-induced changes in soil properties alter the cropping pattern and decrease the yield potential of different crops. The farmers of the study area are aware of recent uncertainty in rainfall patterns as well as temperature change and the resultant impact on crop production. To cope with these adversities, climate-resilient wide yielding varieties of seeds and biofertilizers have been introduced to improve the rate of crop production. However, local farmers are still not well trained to adopt these new farming techniques. They still practice traditional agricultural methods and entrapped in the vicious cycle of poverty due to low economic returns. During the field survey, it was observed that $75 \%$ of the farmers are not well aware of the specificity of different fertilizers for respective crops. The soil fertility and productivity have been decreasing because of excessive application of chemical fertilisers in the soil. Near about $70 \%$ of farmers do not get any strategic help from the government or even any NGOs to enhance their scientific knowledge of agriculture for better productivity. They are practising traditional monocropping instead of the integrated farming system due to lack of skills and monetary constraints. 

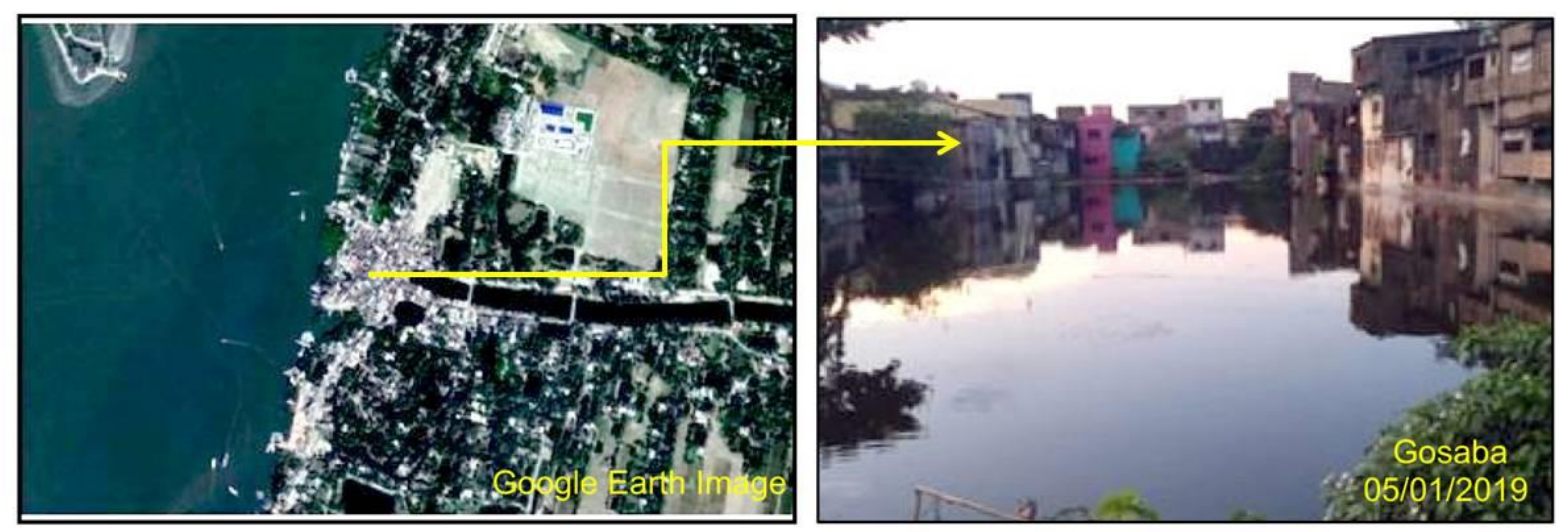

6(a)

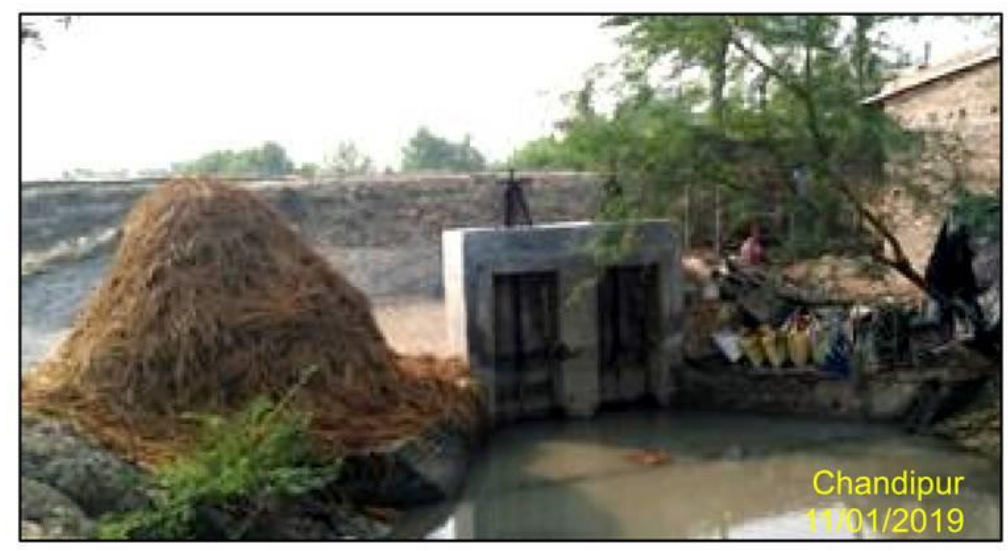

6(b)
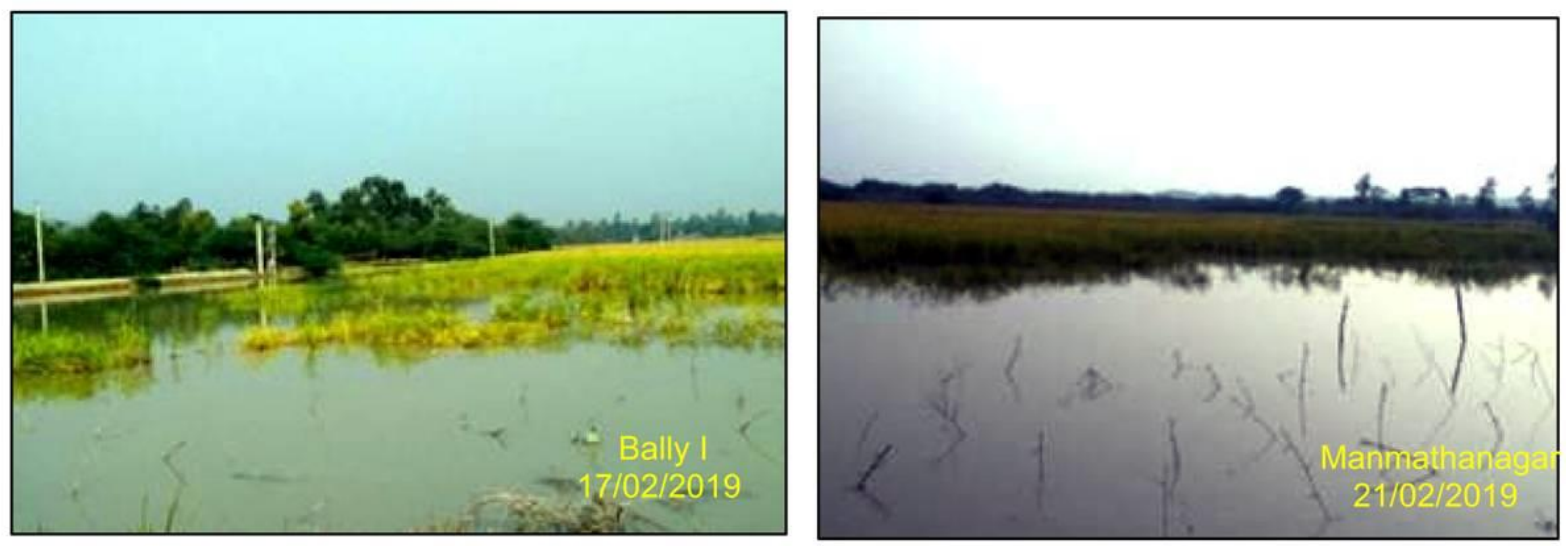

6(c)

Figure 6-Figure 6(a): Drainage Congestion Due to Human Interferences, Figure 6(b): Sluice Gate to Drain out Excess Water of Countryside land Figure 6(c): Waterlogging in Rice Field Source: Field Survey 2018-2019 


\section{Conclusion}

The primary purpose of this study was to foreground the challenges faced by the farmers of Gosaba Island located in Sundarban. Undoubtedly, agriculture is the economic backbone to sustain the basic livelihood of rural people in Gosaba Island. Increasing salinity, waterlogging, lack of irrigation facility and lack of skills about the diversified agricultural system are the major problems of agriculture. The agricultural land remains as a seasonal fallow due to lack of irrigation facility in the dry season. The farmers are not interested in growing vegetables in the post-Aila period due to low productivity and low profitability. There is a slight improvement in the production status of rice during the last four years (2014-2019) as soil salinity is gradually decreasing from $2.3 \%$ in 2010 to $1.8 \%$ o in 2018. Climate change makes the situation more challenging for farmers to sustain their livelihood through agriculture. To ensure food security is a significant challenge for the rapidly growing population (growth rate of $10.7 \%$ in 2011, Census of India) in Gosaba. The low production of crops is directly related to low per capita income of farmers. Therefore climateresilient sustainable and diversified agriculture, proper management of drainage system, rainwater harvesting to improve irrigation facilities and regular training of farmers to cope with modern techniques of agriculture are urgently needed to improve their livelihood through sustainable agriculture.

\section{References}

Allison, M.A. (1998). Geological Framework and Environmental Status of the Ganga Brahmaputra Delta. Journal of Coastal Research, 14(2), 826-836.

Bandyopadhyay, B. K., Maji, B., Sen, H. S., \& Tyagi, N. K. (2003). Coastal soils of West Bengal-their nature, distribution and characteristics. Bulletin, (1), 1-62.

Banerjee, A. (1998). Environment, population, and human settlements of Sundarban Delta. Concept Publishing Company.

Census of India, (2011). Provisional Population Totals. Registrar General and Census
Commissioner of India, Ministry of Home

Affairs, New Delhi, India. Retrieved on 15 March 2019 from,

https://censusindia.gov.in/2011census/dchb/D CHB_A/19/1917_PART_A_DCHB_SOUTH\%20TW ENTY\%20FOUR\%20PARGANAS.pdf

Chakraborty, K., \& Mistri, B. (2018). Unscientific Agricultural Practices and Its Impact on Rural Livelihood in Burdwan-I C.D. Block, Barddhaman, West Bengal. Concept Publishing Company Pvt Ltd, New Delhi, pp. 269-289, ISBN: 13:978-93-86682-26-0.

Das, M., Das, T.K., \& Maji, A. (2012). Managing Embankment Breaching in North-East Sundarban. ACB Publications, Kolkata, 8-17. ISBN: 81-87500-59-X

Danda, A. A., Sriskanthan, G., Ghosh, A., Bandyopadhyay, J., \& Hazra, S. (2011). Indian Sundarbans delta: a vision. World Wide Fund for Nature-India, New Delhi, 40.

Debnath, A. (2013). Condition of Agricultural Productivity of Gosaba C.D. Block, South 24 Parganas, West Bengal, India After Severe Cyclone Aila. International Journal of Scientific and Research Publication, 3(7), 1-4.

District Human Development Report South 24 Parganas (2009). Development \& Planning Department, Government of West Bengal, pp. 1-20 Retrieved on 25 $5^{\text {th }}$ March 2019 from, http://www.undp.org/content/dam/india/docs /hdr_south24_parganas_2009_full_report.pdf.

Dhara, S., \& Paul, A.K. (2016). Status of Agriculture-A Case Study at Patharpratima Block of South 24 Parganas District. International Journal of Innovative Science, Engineering \& Technology, 3(2), 239-246.

Ghosh, S., \& Mistri, B. (2020). Drainage induced waterlogging problem and its impact on farming system: a study in Gosaba Island, Sundarban, India. Spatial Information Research, 1-13. https://doi.org/10.1007/s41324-020-00328-8

Gupta, S., \& Sarkar, G. (2015). Environmental Change and Struggle for Existence: A Case Study of Pakhiralay and Rangabellia Village, Gosaba in Sundarban Area of West Bengal. International 
Journal of Innovation Sciences and Research, 350-354.

Haldar, A., \& Debnath, A. (2014). Assessment of climate induced soil salinity conditions of Gosaba Island, West Bengal and its influence on local livelihood. In Climate Change and Biodiversity (pp. 27-44). Springer, Tokyo. DOI: 10.1007/978-4-431-54838-6_3

Hu, Y., \& Schmidhalter, U. (2002). Limitation of salt stress to plant growth. Plant toxicology, 4, 191-224. DOI:10.1201/9780203023884

Kar, N.S., \& Bandyopadhyay, S. (2015). Tropical Storm Aila in Gosaba Block of Indian Sundarban: Remote Sensing Based Assessment of Impact and Recovery. Geographical Review of India, 77(1), 40-54.

McSweeney, S. L., Kennedy, D. M., \& Rutherfurd, I. D. (2017). A geomorphic classification of intermittently open/closed estuaries (IOCE) derived from estuaries in Victoria, Australia. Progress in Physical Geography, 41(4), 421-449. DOI: $10.1177 / 0309133317709745$

Mahadevia, K., \& Vikas, M. (2012). Climate Change-Impact on the Sundarbans: A Case Study. International Scientific Journal Environmental Science, 20(3), 7-15.

Mandal, S. (2019). Risks and Profitability Challenges of Agriculture in Sundarbans India. In The Sundarbans: A Disaster-Prone EcoRegion (pp. 351-371). Springer, Cham. https://doi.org/10.1007/978-3-030-006808_12

Manuel, R., Machado, A., \& Serralheiro, R. P. (2017). Soil Salinity: Effect on Vegetable Crop Growth. Management Practices to Prevent and Mitigate Soil Salinization. Horticulturae, 3(30), 1-13. doi:10.3390/horticulturae3020030

Mistri, B. (2012). Land use Change and Sustainable Development in Sundarbans: A Geo-Spatial Issue in West Bengal. Geo-Spatial Issues, Dept. of Geography, The University of Burdwan, 30-43. ISBN: 978-93-80813-20-2.

Mistri, B. (2014). Construction of Closure on tidal creeks and its effects: A case study of Patharpratima C.D. Block of Sundarban. Nature and Sustainable Development-Impact of Green Accounting, Published by Academic Staff College, The University of Burdwan. 111-124.

McFeeters, S. K. (1996). The Use of the Normalized Difference Water Index (NDWI) in the Delineation of Open Water Features. International Journal of Remote Sensing, 1425143. DOI: 10.1080/01431160600589179

O'Mally, L. S.S. (1914). Rivers of Bengal, Bengal District Gazetteers. The Bengal Secretariat Book Depot.

Oldham, R.D. (1893). Manual of the Geology of India. $2^{\text {nd }} \mathrm{Ed}$, Geological Survey of India, 427458.

Rogers, K. G., \& Goodbred, S. L. (2014). The Sundarbans and Bengal Delta: the world's largest tidal mangrove and delta system. In Landscapes and landforms of India (pp. 181187). Springer, Dordrecht.

Roy, B., Saha, S.K., Gascon, N.K., \& Hossain, M. (2004). Adoption of Rice-Rice and Rice Fish Farming System in Coastal West Bengal: Determinants and Impact. In: National Symposium on recent advances in Rice-based farming system. CRRI, Cuttack, 107

Shrivastava, P., \& Kumar, R. (2015). Salt Salinity: A Serious Environmental Issue and Plant Growth Promoting Bacteria as one of the Tools for Its Alleviation. Saudi Journal of Biological Science, 22(2), 123-131.

https://doi.org/10.1016/j.sjbs.2014.12.001

Si, S. K. (2016). Analysis of Long Term Impact of Colonic Disaster 'Aila' on Soil Properties and Paddy Yield of Sundarbans, West Bengal, India. Journal of Experimental Biology and Agricultural Sciences, 4(2), 142-148. DOI:

http://dx.doi.org/10.18006/2016.4(2).142.148

Samanta, B. (2018). Changing Scenario of Red Chili Cultivation after Cyclone Aila in Haripur. International Journal of Research and Analytical Reviews, 5(3), 920-925. ISSN 2349-5138

Wong, V.N.L., Greene, R.S.B., Dalal, R.C., \& Murphy, B.W. (2010). Soil Carbon Dynamics in Saline and Sodic Soils: A Review, British Society of Soil Science, Soil Use and Management, 26, 2-11. DOI:10.1111/j.1475-2743.2009.00251.x 


\section{Conflicts of Interest}

The authors declare that they have no conflict of interest.

\section{Acknowledgements}

The first author is thankful to the Tagore Society of Rural Development (TSRD), Rangabellia, and Agriculture and Development Office (ADO) of Gosaba for providing relevant information and data to accomplish this research work. The author is also grateful to UGC, New Delhi, India, for providing the fellowship to conduct the study. Last but not least, authors express their heartfelt gratitude to the anonymous reviewers for minute review of the manuscript and providing valuable suggestions to improve the standard of the manuscript.

\section{Author Contribution Statement}

The first author, Soumen Ghosh collected data through field survey, analysed the data, prepared figures and tables using software and wrote the first research draft. The second author, Dr Biswaranjan Mistri supervised the research work and assisted in developing the final draft of the manuscript by editing and reviewing of the work. 